\title{
The ever evolving MOOC
}

\author{
Patricia A. Young ${ }^{1}$ \\ Published online: 2 February 2021 \\ (c) Association for Educational Communications and Technology 2021
}

The impact of the digital revolution is still under review, because we are living the digital age. The notion that it is possible to educate the world's populace remains our greatest challenge. At one time Massive Open Online Courses (MOOCs) were thought to be the tool to get us there. Stephen Downes and George Siemens 2008 course "Connectivism and Connective Knowledge" is believed to be the first course called a MOOC (Siemens 2004). Sebastian Thrun and Peter Norvig's, professors at Stanford University, 2011 MOOC on Artificial Intelligence attracted 160,000 participants (Davidson 2013). Now the basic MOOC has transformed into cMOOCs (first generation); xMOOCs (second generation) and third generation Hybrid MOOCs (Bozhurt et al. 2018). MOOCs are harbingers of the social media revolution, through platforms like Coursera. Students don't just give their feedback on course content but they provide their personal opinions and vote on peer posts (Loizzo and Ertmer 2016). It would seem that the evolving nature of this digital society is continuing to spill into MOOCs and the future of this medium. That is, what was once a platform devoted to online education is becoming a socialized and politicized online informational tool versus a self-contained educational platform. The merging of these functions speaks to consumers' desire for one platform that provides everything for-educational, social, political, financial, entertainment and personal needs. Consumers want the Walmart of the digital revolution. This one stop shop brings us to this special section.

The importance of MOOCs in the digital age are that they encourage an educated populace by providing a platform to educate hundreds of thousands worldwide. Loizzo and Ertmer's (2016) article proposes MOOCs as a social learning democracy or MOOCocracy. MOOCocracy's comprise both place and space. Adult learners take MOOC courses in the place or locations in which they live around the world. These interactions are asynchronous requiring little formal oversight and even less personal contact. Adult learners take these courses because they are (1) interested in the topic; (2) seek a specific type of knowledge attainment; (3) find it a place to critique the quality of learning as they are consumers of information; (4) find lurking to be learning; (5) revel in their ability as self-sufficient learners or (6) understand peer review as an undesired thorn of MOOCs. The space in which MOOCs take place represents "digital learning cultures on a massive scale" (p. 1016).

This section offers responses from four articles that critique and examine Loizzo and Ertmer's (2016) study. Paek approaches the article from a research perspective by elaborating on the value of a social learning democracy and proposes that "shifting to digital" is

Patricia A. Young

pyoung@umbc.edu

1 University of Maryland Baltimore County, 1000 Hilltop Circle, Baltimore, MD 21250, USA 
more about students controlling their learning environment. Akinkuolie \& Shortt approach the article from a design perspective and provide suggestions for the future of MOOCs based on six online learning culture themes. Hu \& Spiro take a theoretical approach by focusing on Cognitive Flexibility Theory and argue for a reorientation of the epistemic standpoint of online learning to include adaptive worldviews and learner skills. Finally, Whitworth digs deeper to examine teacher and student practices within MOOCs.

\section{References}

Bozkurt, A., Kilgore, W., \& Crosslin, M. (2018). Bot-teachers in hybrid massive open online courses (MOOCs): A post-humanist experience. Australasian Journal of Educational Technology, 34(3), 39-59. https://doi.org/10.14742/ajet.3278.

Davidson, C. (2013). What was the first MOOC? Retrieved from https://www.hastac.org/blogs/cathy-david son/2013/09/27/what-was-first-mooc.

Loizzo, J., \& Ertmer, P. A. (2016). MOOCocracy: The learning culture of massive open online courses. Educational Technology Research and Development, 64, 1013-1032. https://doi.org/10.1007/s1142 3-016-9444-7.

Siemens, G. (2004). Connectivism: A learning theory for the digital age. Paris: E LearnSpace.

Publisher's Note Springer Nature remains neutral with regard to jurisdictional claims in published maps and institutional affiliations.

Patricia A. Young PhD, is an educational technologist, professor and software developer. She is Program Director of Elementary Education and Associate Professor in the Department of Education at the University of Maryland Baltimore County. Her research examines culture and the design of information and communication technologies and the history of educational technologies designed by and for African Americans. 